TAHKIM, Jurnal Peradaban dan Hukum Islam. Vol.4 No.l (Maret, 2021) | ISSN : 2597-7962

\title{
ANALISIS SYARAT IN'IQAD DARI 'AQIDAIN DAN SHIGHAT DALAM PEMBENTUKAN SEBUAH AKAD SYARIAH
}

\author{
Dery Ariswanto \\ Magister Hukum Ekonomi Syariah \\ Universitas Islam Negeri (UIN) Sunan Gunung Djati Bandung \\ dery0712@gmail.com
}

\begin{abstract}
ABSTRAK
Paper ini bertujuan untuk menjelaskan dan menganalisis tentang syarat in'iqad dari 'aqidain (para pihak) dan shighat (ijab qabul) dalam pembentukan sebuah akad syariah serta aplikasinya pada kegiatan ekonomi. Berdasarkan studi literatur yang dilakukan penulis, maka dapat diketahui bahwa pembentukan sebuah akad akan dapat terwujud apabila telah terpenuhi segala unsur-unsurnya yang diterjemahkan melalui rukun akad. Rukun akad yang masyhur dalam kalangan pemerhati fiqh muamalah meliputi para pihak yang berakad ('aqidain), objek yang diakadkan (ma'qud 'alaih), tujuan atau maksud mengadakan akad (maudhu' al-'aqad), dan sighat al-'aqad (ijab dan qabul). Syarat in'iqad pada para pihak yang mengadakan akad meliputi tamyiz dan berbilang. Sedangkan syarat in'iqad pada pernyataan kehendak (shighat) harus terjadi persesuaian antara ijab dan qabul serta harus dalam kesatuan majlis. Syarat-syarat tersebut harus dipenuhi agar akad yang dilaksanakan dapat sah dan berlaku kepada kedua belah pihak. Apabila syarat tersebut tidak terpenuhi, maka transaksi ekonomi yang dilakukan tersebut akan bernilai tidak sah sehingga tidak dapat membentuk sebuah akad yang sesuai dengan prinsip syariah.
\end{abstract}

Kata Kunci: Akad syariah, rukun akad, syarat in'iqad.

ABSTRACT

This paper aims to explain and analyze the in 'iqad requirements of 'aqidain (parties) and shighat (ijab qabul) in the formation of a sharia contract and its application to economic activities. Based on the literature study conducted by the author, it can be seen that the formation of a contract will be realized if all the elements have been fulfilled which are translated through the pillars of the contract. The well-known pillars of the contract among observers of fiqh muamalah include parties who have contracted ('aqidain), objects that are acclaimed (ma'qud' alaih), the purpose or intention of making a contract (maudhu 'al-'aqad), and sighat al-'aqad (consent and qabul). The terms of in'iqad on the parties who enter into the contract include tamyiz and multiplication. Meanwhile, the in'iqad requirement in the statement of the will (shighat) there must be an agreement between consent and qabul and must be in the unity of the majlis. These conditions must be fulfilled so that the contract that is carried out can be valid and valid for both parties. If these conditions are not met, the economic transaction carried out will be invalid so that it cannot form a contract in accordance with sharia principles.

Keywords: In'iqad terms, pillars of the contract, sharia contract. 
TAHKIII, Jurnal Peradaban dan Hukum Islam. Vol.4 No.l (Maret, 2021) | ISSN : 2597-7962

\section{A. PENDAHULUAN}

Manusia sebagai makhluk sosial dalam pemenuhan kebutuhannya pasti memerlukan support dari manusia lainnya. Dalam ranah agama Islam, hubungan antar sesama manusia diistilahkan dengan hablum minannas. Kegiatan antar manusia juga diidentikkan dengan sebutan mu'amalah, istilah tersebut dapat diartikan sebagai hubungan antar manusia sebagai makluk yang tidak dapat hidup sendiri yang berlandaskan aturan syariah. Syariah merupakan komponen dalam ajaran agama Islam yang mengatur kehidupan umat muslim dalam aspek ibadah juga dalam aspek mu'amalah, sebagai bentuk aktualisasi dari akidah sesorang yang menjadi keyakinannya. Kegiatan mu'amalah meliputi berbagai aspek kehidupan manusia, salah satunya menyangkut ekonomi, harta dan perniagaan yang dikenal dengan mu'amalah maliyah.

Al-Qur'an telah secara tegas memberikan batasan-batasan bagi manusia untuk menjalankan kegiatan yang bersifat sosialnya, terkhusus dalam hal ekonomi. Sebagaimana aktivitas perekonomian yang dilarang seperti halnya adanya larangan kegiatan yang mengandung riba, gharar, maisyir dan hal lain yang dapat merugikan salah satu pihak. Jual beli menjadi salah satu transaksi halal yang paling sering digunakan oleh manusia dalam kesehariannya. Sesungguhnya aspek terpenting dari jual beli adalah adanya akad. Akad menjadi kunci dari sebuah transaksi atau kegiatan ekonomi. Apabila sebuah transaksi yang akadnya dilakukan dengan sempurna sesuai aturan syariah, maka dapat dipastikan akad tersebut menjadi sah. Namun sebaliknya, apabila dalam kegiatan yang dibolehkan semisal jual beli terdapat suatu kecacatan atau kekurangan dari setiap syarat dari unsur pembentuk akad maka akad tersebut belum dapat dikatakan sah bahkan batal dan tidak mengikat bagi kedua belah pihak yang menyutujuinya.

Akad merupakan hal sentral dalam ranah pembahasan fiqh muamalah karena akad adalah cara memperoleh suatu tujuan dan maksud dari seseorang yang erat kaitannya dengan keyakinan serta senada dengan ajaran syariah Islam. Berdasarkan realitas yang ada, justru masih banyak ditemukan kejanggalan dan kekurangan dalam melangsungkan sebuah akad. Kesalahan yang sering dijumpai di masyarakat Indonesia dalam menjalankan kegiatan 
TAHKIM, Jurnal Peradaban dan Hukum Islam. Vol.4 No.l (Maret, 2021) | ISSN : 2597-7962

ekonomi dan pemenuhan kebutuhannya adalah tidak sempurnanya syarat dan rukun akad, sehingga berpotensi untuk menimbulkan celah persengketaan dan merugikan salah satu pihak. Bahkan jika tidak memperhatikan rukun dan syarat dari sebuah akad yang akan dilaksanakannya, akibatnya akad tersebut menjadi tidak sah berdasarkan hukum Islam.

Setiap akad memiliki unsur pembentuknya, unsur pembentuk tersebut diistilahkan penulis sebagai rukun akad. Sebagaimana banyak disinggung dalam literatur fiqh, rukun akad secara umum terdiri dari para pihak yang berakad ('aqidain), sighat akad berupa ijab dan qabul, ma'qud 'alaih atau objek akad, dan maudhu'ul akad atau tujuan/maksud akad. Rukun akad tersebut di atas tidak dapat berdiri sendiri dalam pembentukan sebuah akad, melainkan membutuhkan penunjang dengan adanya batasan dan ketentuan khusus dari setiap unsurnya. Ketentuan itu diwujudkan dengan adanya syarat-syarat akad. Syarat akad pasti melekat pada setiap unsur yang ada baik dari para pihak yang melaksanakan akad sampai tujuan akad itu sendiri.

Berbicara mengenai syarat berlakunya sebuah akad (in'iqod), syarat ini merupakan syarat umum yang melekat dan harus selalu ada dalam akad, semisal syarat yang harus ada pada pelaku akad, sighat, objek akad, dan tujuan akad. Di antara syarat-syarat yang harus ada pada pelaku akad adalah masuk usia tamyiz dan berbilang. Sedangkan syarat dalam shighat akad yakni setidaknya harus ada persesuaian antara ijab-qabul dan berada dalam kesatuan majelis.

Permasalahan yang masih sering timbul di tengah masyarakat terkait dengan syarat in'iqad pada pelaku akad dan sighatnya adalah bagaimanakah status hukum akad yang dilakukan oleh anak yang belum dewasa, kaitannya dengan kecakapan untuk berbuat. Tidak kalah ramainya juga, persoalan sebuah akad yang dilakukan oleh dua pihak tanpa ada ijabqabul secara jelas semisal transaksi yang berkembang di era modern seperti e-mart, minimarket dan lain-lain. Serta kejelasan transaksi/ akad yang dilaksanakan melalui online karena tidak nampak secara dzahir di satu majlis akad. Beberapa masalah tersebut muncul karena masih sedikit pemahaman masyarakat terkait fiqh muamalah masih sangat kurang, juga dipengaruhi oleh perubahan zaman seiring dengan kemajuan ilmu pengetahuan dan teknologi. Hukum ekonomi syariah dalam hal ini harus mampu menyesuaikan dan 
TAHKIM, Jurnal Peradaban dan Hukum Islam. Vol.4 No.l (Maret, 2021) | ISSN : 2597-7962

memberikan kepastian hukum terhadap persoalan-persoalan perekonomian baru dengan dasar Al-Qur'an, Hadist, Ijma' dan landasan hukum lainnya, seperti UU perbankan syariah, KHES dan Fatwa DSN MUI.

Sehingga dalam kesempatan ini penulis mencoba untuk membahas mengenai teori akad yang menitik-beratkan kepada rukun dan syarat akad pada bagian para pihak yang mengadakan akad serta shighat akadnya yakni ijab dan qabul dengan mengambil pembahasan melalui judul analisis syarat in'iqad dari 'aqidain (para pihak) dan shighat (ijab qabul) dalam pembentukan akad syariah serta aplikasinya pada kegiatan ekonomi.

\section{B. METODE PENELITIAN}

Penyusunan artikel ini tidak terlepas dari adanya metode penelitian, adapun penelitian ini ialah penelitian kualitatif dengan memakai metode dekskriptif-analisis, yakni suatu metode yang bertujuan untuk mendeskripsikan secara mendalam sebagai upaya untuk memberikan tanggapan, revisi, dan pilihan lain juga solusinya terhadap problematika yang terdapat pada penelitian ini. ${ }^{1}$ Adapun penelitian ini akan menggambarkan terkait analisis syarat in'iqad dari 'aqidain (para pihak) dan shighat (ijab qabul) dalam pembentukan akad syariah serta aplikasinya pada kegiatan ekonomi dan menganalisa menggunakan kajian hukum Islam.

Jenis penelitian ini ialah studi kepustakaan, yakni penelitian yang dihasilkan atas kajian literatur terkait pengelolaan syarat in'iqad dari 'aqidain (para pihak) dan shighat (ijab qabul) dalam pembentukan akad syariah serta aplikasinya pada kegiatan ekonomi yang mencakup jurnal, buku-buku, peraturan perundang-undangan, dan rujukan lainnya yang masih terkait. Sedangkan teknik analisis data dalam penelitian ini yaitu teknik analisis data yang bersifat induktif yakni suatu metode untuk menganalisis data yang bermula dari fakta atau problematika yang sifatnya spesifik lalu disimpulkan ke dalam bentuk yang sifatnya general. ${ }^{2}$ Peneliti dalam hal ini berangkat atas fakta empirik tentang syarat in'iqad dari 'aqidain (para pihak) dan shighat (ijab qabul) dalam pembentukan akad syariah serta

\footnotetext{
${ }^{1}$ Moh. Nadzir, Metodologi Penelitian, (Jakarta: Ghalia Indonesia, 1998). hlm. 12.

${ }^{2}$ Sutrisno Hadi, Metodologi Riset (Yogyakarta: Pustaka Belajar, 2019). hlm. 34.
} 
TAHKIM, Jurnal Peradaban dan Hukum Islam. Vol.4 No.l (Maret, 2021) | ISSN : 2597-7962

aplikasinya pada kegiatan ekonomi. Kemudian mencatat, menganalisis, dan mereview sehingga menghasilkan suatu simpulan yang relevan dan mampu menjawab permasalahan.

\section{PEMBAHASAN}

\section{Pembentukan Akad dalam Hukum Akad Syariah}

Lafadz akad secara bahasa berasal dari bahasa Arab yaitu al- 'aqdu yang dalam versi jamaknya adalah al- 'uqud yang memiliki arti ikatan atau tali pengikat. ${ }^{3}$ Lafadz 'aqd oleh ulama fiqh dimaknai sebagai suatu bentuk hubungan antara ijab dan qabul yang sesuai dengan syariat Islam sehingga menuntut adanya akibat hukum yang ditimbulkan. Akad dalam istilah fiqh secara umum diartikan sebagai sebuah sarana yang menjadi tekad manusia untuk melakukan sesuatu. Pelaksanaan akad tersebut dapat terwujud atas kepentingan sepihak selayaknya wakaf, sumpah, talak dan lainnya. Juga dapat terbentuk atas kepentingan dua pihak atau lebih misalnya kegiatan jual beli, wakalah, sewa, dan lain semacamnya. Akad secara khusus merupakan bentuk kesetaraan antara pernyataan kehendak atau ijab dengan pernyataan penerimaan atau qabul dalam ranah yang diisyaratkan dan berpengaruh pada sesuatu. ${ }^{4}$

Ahli fiqh atau fuqoha' telah merumuskan makna dari akad sebagaimana penjelasan berikut ini:

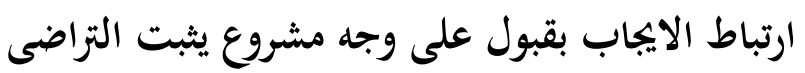

Dengan bahasa lain diartikan sebagai sebuah perikatan antara ijab dan qabul dengan cara yang dibenarkan syara', yang menetapkan keridahan kedua belah pihak. ${ }^{5}$ Akad menurut pengertian lain secara istilah merupakan sebuah pertalian antara ijab dan qabul yang tidak bertentangan dengan syariat yang berpengaruh kepada objek akad, dengan kata lain harus sesuai dengan kehendak syariat dan memiliki konsekuensi adanya perpindahan kepemilikan. ${ }^{6}$

\footnotetext{
${ }^{3}$ Abdul Aziz Muhammad Azzam, Fiqih Muamalat, (Jakarta: Amzah, 2010), hlm.15

${ }^{4}$ Ascarya, Akad Dan Produk Bank Syariah, (Jakarta: Rajawali Pers, 2007), hlm. 35

${ }^{5}$ Hasbi Ash-Shiddieqy, Pengantar Fiqh Mua'malah, (Semarang: Pustaka Rizki Putra, 2007) hlm. 21.

${ }^{6}$ Abdul Azis Dahlan, Ensiklopedi Hukum Islam, Jilid I Cet. I (Jakarta: Ichtiar Baru Van Hoeve, 1996),
} hlm. 63 
TAHKIM, Jurnal Peradaban dan Hukum Islam. Vol.4 No.l (Maret, 2021) | ISSN : 2597-7962

Dalam kajian fiqh mu'amalah, terdapat perbedaan pengertian antara wa'ad dengan akad. Sebagaimana wa'ad hanya merupakan sebuah janji antar dua pihak, sedangkan akad merupakan kontrak mengikat antara dua belah pihak yang bersifat pasti. Dengan kata lain, wa'ad hanya mengikat kepada salah satu pihak saja yakni pihak yang berjanji. Dialah yang memiliki kewajiban untuk menepati janjinya. Sementara itu orang yang diberikan janji tidak sebuah kewajiban apapun kepada pihak yang lain. Trems and condition dalam wa'ad belum ditetapkan spesifik. Sanksi atas pelanggarannya hanya bersifat sanksi moral. ${ }^{7}$ Berbeda hal dengan akad, karena sesungguhnya akad bersifat mengikat keduabelah sehingga timbul konsekuensi dengan adanya hubungan hak dan kewajiban antar keduanya serta telah ditetapkan terms and condition-nya secara rinci. Sanksi atas pelanggarannya seperti yang disepakati dalam akad atau sesuai aturan hukum yang berlaku. $^{8}$

Takwin al-Aqd atau pembentukan sebuah akad akan dapat terwujud apabila telah terpenuhi segala unsur-unsurnya. Adapun unsur-unsur tersebut yaitu arkan al-aqd atau rukun akad dan syurut al-aqd atau syarat-syarat akad. ${ }^{9}$ Setelah diketahui bahwa akad adalah sebuah perbuatan yang dengan sengaja dibuat oleh dua pihak atau lebih yang berlandaskan keridho'an, maka akan muncul rukun akad. Rukun akad yang masyhur meliputi para pihak yang berakad ('aqidain), objek yang diakadkan (ma'qud 'alaih), tujuan atau maksud mengadakan akad (maudhu' al-'aqad), dan sighat al-'aqad (ijab dan qabul).

Semetara itu menurut Wahbah Az-Zuhaily, yang dimaksud dengan unsur akad yaitu penopang munculnya akad. Unsur yang disebut terdiri atas empat hal yakni shighat, ta'aqud (proses akad), 'aqidain (dua orang pengakad), mahal dan maudhu' akad. ${ }^{10}$ Apabila dalam sebuah kesepakatan telah terpenuhi semua rukunnya, maka kesepakatan tersebut dapat dikatakan sebagai akad karena sudah memenuhi subtansinya. Namun, akad tersebut

${ }^{7}$ Adiwarman A. Karim, Bank Islam Analisis Fiqih dan Keuangan Edisi III (Jakarta: Raja Grafindo, 2007), hlm. 65

${ }^{8}$ Ibid.., hlm. 65

${ }^{9}$ Nurul Ichsan Hasan, Perbankan Syariah: Sebuah Pengantar. Jakarta: Referensi GP Press Group. hal. 193.

${ }^{10}$ Wahbah Az-Zuhaily, Al-Fiqh Al-Islami Wa Adillatuhu IV, (Damaskus: Dar al-Fikr, 1989) hlm, 430. 
baru dapat dikatakan sah berlaku apabila terpenuhi juga syarat-syarat akad yang melekat pada setiap rukunnya. ${ }^{11}$ Sedangkan syarat oleh ulama fiqh diartikan sebagai segala sesuatu yang terkait pada tidak adanya sesuatu yang lain, maksudnya adalah bahwa tidak dikaitkan pada adanya sesuatu yang lain dan bersifat eksternal. ${ }^{12}$

Az-Zarqa dalam sisi lainnya menyatakan bahwa terdapat istilah lain dalam pengistilahan tentang rukun dalam akad. Istilah muqawwimat akad digunakan untuk memjelaskan makna yakni sebagai unsur penegak akad, di dalamnya ada rukun akad meliputi ijab dan qabul, sedangkan unsur yang lainnya di mana salah satunya adalah rukun akad, ijab dan qabul. Sedangkan para pihak, objek akad dan tujuan akad merupakan salah satu unsur lainnya. ${ }^{13}$

\section{Syarat In'iqad Para Pihak ('Aqidain) dalam Akad Syariah}

Syarat In 'iqod merupakan syarat-syarat terbentuknya akad, syarat tersebut ada yang bersifat umum dan juga khusus. Syarat umum yang dimaksud adalah syarat yang melekat dan harus selalu ada dalam akad, semisal syarat yang harus ada pada pelaku akad, sighat, objek akad, dan tujuan akad. Sedangkan syarat khusus dalam hal ini yakni sesuatu yang harus ada pada akad-akad tertentu, seperti syarat minimal dua saksi pada akad nikah. ${ }^{14}$

Pelaku akad atau para pihak yang mengadakan akad merupakan tokoh sentral yang memiliki peran sebagai subjek dalam menjalankan esensi akad yakni ijab-qabul, tanpa kedua belah pihak tersebut akad tidak akan dapat terbentuk. Adapun syarat yang melekat dan harus dipenuhi oleh para pihak yang mengadakan akad adalah sebagai berikut:

a. Telah masuk kategori tamyiz

Sebuah akad yang mencakup ijab dan qabul di dalamnya harus dinyatakan oleh para pihak yang mengadakan akad apabila telah memasuki kategori tamyiz, artinya pada posisi itu dia telah bisa menyadari dan mengetahui isi dari perkataan yang diucapkannya. Artinya, dari ucapan atau penyampaian kehendaknya tersebut dapat

\footnotetext{
${ }^{11}$ Mardani, Fiqih Ekonomi Syariah, (Jakarta: Kencana, 2012), hlm. 74

${ }^{12}$ Mustafa Ahmad az-Zarqa, Aal-Madkhal al-Fiqh al'Am. (Beirut: Dar al-Fikr, tt), I: hlm. 300.

${ }^{13}$ Ibid.., hlm, 301

14 Teungku Muhammad Hasbi Ash-Shiddieqy, Pengantar Fiqh Mua'malah, cet. Ke-4, (Semarang: Pustaka Rizki Putra, 2013), hal. 29.
} 
TAHKIM, Jurnal Peradaban dan Hukum Islam. Vol.4 No.l (Maret, 2021) | ISSN : 2597-7962

mencerminkan sebenar-benarnya keinginan hati. Ijab dan qabul di sini harus dinyatakan oleh orang yang sudah cakap untuk melakukan tindakan hukum.

Berdasarkan segi kecakapan melaksankan akad, seseorang dapat dimungkinkan untuk cakap melaksanakan sesuatu itu terbagi menjadi tiga kategori yakni sebagian tidak mampu melangsungkan akad apapun, sebagian cakap melangsungkan akad tertentu dan sebagian yang lainnya cakap melakukan untuk semua akad. Pembedaan kategori ini sangat bergantung pada sejauhmana seseorang memiliki kelayakan atau kecakapan melakukan sebuah persoalan, yang dalam istilah fiqh diidentikkan dengan sebagai ahliyyah yakni sebuah kelayakan melakukan akad. Ahliyyah didefenisikan oleh ahli ushul sebagai sebagai sebuah bentuk kecakapan seseorang untuk memiliki hak dan memikul kewajiban, serta memiliki kecakapan untuk bertasarruf. ${ }^{15}$ Kecakapan dapat dikategorikan menjadi dua yaitu ahliyatul wujub artinya kecakapan untuk menerima sebuah hukum (sifatnya pasif) dan ahliyatul ada' artinya kecakapan bertindak hukum (sifatnya aktif). ${ }^{16}$

Ahliyyatul wujub merupakan sebuah kecakapan seseorang untuk memiliki sejumlah hak yang bersifat kebendaan, contohnya seperti hak atas ganti rugi dan hak waris. Sumber dari ahliyyatul wujub berasal dari kehidupan dan kemanusiaan. Sehingga seseorang dipandang cakap memiliki hak jika masih memiliki nyawa dalam hidupnya. Janin yang masih berada di dalam kandungan ibunya juga memiliki hak tersebut, namun tentunya kecakapan itu sifatnya masih belum sempurna karena dalam dirinya hanya terbatas untuk menerima beberapa hak dan tidak dapat dibebankan menerima sebuah kewajiban. Kecakapan semacam ini disebut dengan ahliyyatul wujub an-naqisah yaitu kecakapan menerima hukum tidak sempurna.

Kecakapan menerima hukum tersebut dapat berubah menjadi sempurna apabila ia sudah terlahir ke dunia, maka dengan demikian ia telah cakap menerima hak dan kewajiban hingga meninggal. Kecakapan ini tidak berlaku secara mutlak melainkan akan didapatkan secara bertahap sebagaimana pada masa kanak-kanak akan sangat

\footnotetext{
${ }^{15}$ Wahbah Az-Zuhaili. Al-Fiqh Al-Islami.., IV, hlm, 116-117.

${ }^{16}$ Hasbi ash-Shiddieqy. Pengantar Fiqih Mua'malah. (Jakarta: Bulan Bintang, 2007) hlm, 20
} 
terbatas, lalu berlanjut pada kategori tamyiz dan dewasa. ${ }^{17}$ Sedangkan Ahliyyatul ada' diartikan sebagai sebuah kecakapan seseorang dalam melakukan tindakan hukum (tasarruf), yang dengan itu akan dikenakan tanggung-jawab atas kewajiban yang melekat dari tindakan tersebut. Sehingga melalui pernyataan kehendak tersebut akan melahirkan akibat hukum. Sandaran dalam kecakapan ini yaitu sifat tamyiz (mampu membedakan dua hal berbeda, misalnya baik dan buruk) dan berakal sehat. Belum sempurnanya kecakapan pada usia tamyiz dikarenakan pada usia tersebut tindakan hukum yang dilakukannya hanya sah dan terbatas dalam tindakan tertentu. Maka seorang mumayyiz yang berakal sehat memiliki kecakapan bertindak tidak sempurna yang disebut ahliyyatul ada' an-naqisah. ${ }^{18}$.

Batas usia tamyiz yang dikemukakan oleh ulama figh sesungguhnya dapat dikategorikan menjadi dua yakni 7 tahun untuk kriteria yang berlaku dalam hal ibadah, sedangkan 12 sampai 18 tahun dalam urusan harta kekayaan. Oleh karena itu, konteks pemaknaan tamyiz dalam hal ini lebih condong ke kategori kedua, karena usia 12 tahun merupakan usia ketika anak sudah dapat melakukan tindakan yang murni menguntungkan. Usia di bawah itu dipandang masih belum cukup matang karena masih anak-anak. ${ }^{19}$ Persoalan demikian juga senada dengan apa yang dicantumkan di pasal 105 Kompilasi Hukum Islam terkait pembatasan usia tamyiz adalah pada usia 12 tahun. $^{20}$

Adapun fase perkembangan yang dialami oleh manusia terkait dengan kecakapan hukum melakukan sesuatu pada harta kekayaan adalah sebagai berikut: Pertama, fase janin yaitu saat subjek hukum telah memiliki kecakapan menerima hukum yang tidak sempurna. Kedua, fase anak-anak yakni umur 0 hingga tepat 11 tahun, fase ini memiliki kecakapan menerima hukum sempurna, namun hanya dapat menerima kewajiban terbatas. Ketiga, mumayyiz yaitu usia 12 sampai usia 18 tahun yang telah mempunyai kecapakan bertindak hukum tidak sempurna namun juga memiliki kecakapan

\footnotetext{
${ }^{17}$ Syamsul Anwar, Hukum Perjanjian Syariah..., hlm. 111

${ }^{18}$ Ibid, hlm. 112-113

${ }^{19}$ Ibid, hlm. 33

${ }^{20}$ Afdawaiza, Terbentuknya Akad, Jurnal Al-Mawarid Edisi XVIII (2008), hlm. 186.
} 
TAHKIM, Jurnal Peradaban dan Hukum Islam. Vol.4 No.l (Maret, 2021) | ISSN : 2597-7962

menerima hukum sempurna. Dan keempat, orang berusia genap 18 tahun yakni orang dewasa yang telah memiliki kecakapan bertindak hukum dan menerima hukum sempurna. $^{21}$

Sementara menurut Wahbah Zuhaily, seorang manusia sejak awal kehidupannya di dalam perut ibunya sampai menjadi seorang yang dewasa akan melalui lima fase yaitu fase janin, fase anak-anak (belum mumayyiz), fase mumayyiz, fase baligh, dan fase ar-rusyd (berakal sempurna atau dewasa). ${ }^{22}$ rusyd diartikan sebagai sebuah sikap yang benar dan terkendali dalam tindakan mengelola kekayaan. ${ }^{23}$ Rusyd dalam bahasa Indonesia dapat diartikan sebagai sebuah kematangan. Madzhab Hanafi memberikan ketentuan batas umur dewasa atau rusyd yaitu saat seseorang telah memasuki umur 18 atau 19 tahun, karena pada usia tersebut kondisi anak telah matang baik secara psikis maupun fisik tanpa pembedaan antara laki-laki atau perempuan. Hal demikian juga seiring dengan adat atau kebiasaan yang berkembang di tengah masyarakat yang beranggapan bahwa usia matang adalah apabila telah memasuki usia 18 tahun. $^{24}$

Di Indonesia banyak dijumpai bahkan sudah menjadi hal umum bahwa anak kecil yang sudah bertransaksi jual beli baik di kantin sekolah atau di masyarakat sekitar, bahkan tidak jarang dijumpai dengan anak kecil yang sudah bekerja akibat perekonomian keluarga yang kurang. Lantas bagaimakah status kebolehan anak kecil yang melakukan akad tersebut, apakah status akadnya sah atau terdapat ketentuan yang lain. Hal ini hanya dapat dikaji berdasarkan terpenuhinya atau tidak, syarat-syarat dalam akad yang dilaksakan. Secara spesifik akan dapat diketahui statusnya pada pembahasan syarat in 'iqad para pihak yang berakad.

Taqiyuddin Al-Hushny dalam hal ini menyatakan bahwa salah satu syarat dalam sebuah akad adalah harus dilaksanakan oleh ahlinya baik penjual atau pembeli, sehingga tidak sah jual beli dari anak kecil, orang gila, dan orang bodoh. ${ }^{25}$ Erat

\footnotetext{
${ }^{21}$ Wirdyaningsih Gemala Dewi dan Yeni Salma Barlint, Hukum Perikatan Islam di Indonesia, (Jakarta: Kencana, 2006) hlm. 52-54

${ }^{22}$ Wahbah Az-Zuhaily. Al-Figh Al-Islami..., hlm, 455.

${ }^{23}$ Ibid.., hlm. 114

${ }^{24}$ Ahmad Azhar Basyir, Asas-asas Hukum Muamalat, (Yogyakarta: UII Press, 2000) hlm. 32.

${ }_{25}$ Taqiyuddin Abu Bakar bin Muhammad Al-Hushny, Kifayatul Akhyar fi Hilli Ghayatil Ikhtishar, (Surabaya: Al-Hidayah, 1993) hlm, 239.
} 
TAHKIM, Jurnal Peradaban dan Hukum Islam. Vol.4 No.l (Maret, 2021) | ISSN : 2597-7962

kaitannya juga dengan syarat mutlak pada pengelolaan harta atau dalam bahasa arab disebut mutlaqu al-tasharuf yang meliputi dewasa, berakal, cakap, dan bukan atas keterpaksaan. Sayyid Muhammad Bin Muhammad Al-Ba'alawy menyantumkan syarat-syarat barang yang dibeli oleh anak kecil yakni adanya ijma' ulama yang memboleh mengutus anak kecil untuk memenuhi beberapa kebutuhan dan membeli perkara yang remeh, baik tanpa seizin wali maupun atas seizinnya. ${ }^{26}$

Kegiatan jual beli yang dilakukan anak kecil dapat dikatakan sah apabila barang atau objek yang dibeli merupakan sebuah barang yang remeh seperti snak, mainan dan lain sebagainya dalam jumlah sedikit. Hal ini dibolehkan oleh jumhur ulama kecuali Imam Ahmad yang menyatakan boleh sampai dengan jumlah yang banyak. Berdasarkan uraian pendapat ulama di atas, maka hukum dari anak kecil yang melakukan transaksi jual beli adalah sah untuk barang-barang yang bersifat remeh (alhaqir) dan tidak mahal. Hukumnya disamakan dengan jual beli mu'athah, yaitu jual beli saling mengulurkan sesuatu tanpa shighat ijab qabul. Kelonggaran hukum ini sudah pasti harus disertai catatan bahwa wajib bagi orang tua bertanggung jawab dalam melakukan pengawasan dan pendampingan. Seperti mengawasi kemanfaatan barangnya dan segi mudharatnya. Syarat sah dalam jual beli mu'athah menurut madzhab Maliki dan Hanafi yaitu selama kegiatan tersebut menjadi kebiasaan di tengah masyarakat setempat sehingga menunjukkan adanya keridhaan dari kedua belah pihak, maka diperbolehkan. Sedangkan lebih khusus dari madzhab Syafi'i memebrikan ketentuan terkait syarat sahnya jual beli mu'athah ini yaitu harus ada penyampaian lafadz ijab dan qabul baik dengan lisan secara jelas atau dengan tulisan.

Penulis lebih sepakat dengan diperbolehkannya aktivitas muamalah ini jika dikaitkan dengan syarat harus tamyiz yakni boleh melakukan transaksi akad namun sifatnya masih terbatas harus atas pengawasan dari walinya. Sesunggunya terdapat beberapa alasan atau motif yang dapat dijadikan sebagai pertimbangan dalam merumuskan sebuah hukum dalam perdebatan ini, adapun konteks yang terjadi adalah

\footnotetext{
${ }^{26}$ Sayyid Abdurrahman bin Muhammad al-Ba'alawy, Bughyatul Mustarsyidin, (Beirut: Darul Kutub Ilmiyah, tt) hlm,124.
} 
TAHKIM, Jurnal Peradaban dan Hukum Islam. Vol.4 No.l (Maret, 2021) | ISSN : 2597-7962

seperti berikut. Terkadang yang melalukan akad adalah anak yang sudah tamyiz, berakal dan cakap namun belum dewasa. Biasanya barang yang dibeli sebatas hal biasa yang bernilai rendah serta tidak mengandung madharat. Transaksi semacam itu sudah menjadi kebiasaan di tengah masyarakat. Orang tua memiliki keharusan untuk mengawasi sebagai walinya terhadap apa yang dibeli oleh anak kecil. Berdasarkan hal demikian, banyak ulama yang menyakan bahwa praktik jual beli yang dilakukan oleh anak kecil sebatas transaksi kecil adalah boleh.

b. Harus berbilang

Terwujudnya akad disamping harus dilakukan oleh para pihak yang sudah masuk kategori tamyiz, akad harus dilakukan secara berbilang oleh dua belah pihak. Karena hakikat dari akad adalah pertemuan antara satu pihak yang berijab dan pihak lain yang memberi qabul. Sehingga akad tidak akan pernah terwujud apabila dilakukan hanya oleh satu orang. Dalam bebrapa kasus terkadang ada salah satu pihak yang memberikan perwakilan kepada orang lain untuk melaksanakan akad atas nama dirinya. Demikian pula seseorang dapat menjadi wakil bagi orang lain untuk melakukan sebuah transaksi. Sehingga mengakibatkan tidak menutup kemungkinan seseorang melakukan akad dengan dirinya sendiri. Baik sebagai pihak asli yang bersifat prinsipil atau pihak lain dalam waktu yang sama juga menjadi wakil pihak yang lainnya. Atau dapat sekaligus menjadi wakil dari dua pihak dalam melakukan akad.

Bentuk kedua akad perwakilan ini adalah tidak sah, karena pada asasnya dalam hukum Islam penutupan perjanjian dengan diri sendiri tidak boleh dilakukan kecuali ayah atau kakek yang mewakili anak atau cucu di bawah perwaliannya. ${ }^{27} \mathrm{Hal}$ ini karena tindakan tersebut membawa pertentangan kepentingan sebab satu orang yang sama menjadi kreditor dan debitur serta penyerah dan penerima sekaligus dalam waktu yang sama. Satu orang yang sama tidak dapat menjadi sangkutan hak-hak yang saling berhadapan. ${ }^{28}$

${ }^{27}$ Muhammad Hashim Kamali, Prinsip dan Teori-teori Hukum Islam, (Yogyakarta: Pustaka Pelajar, 1996) hlm. 162.

${ }^{28}$ Syamsul Anwar, Hukum Perjanjian Syariah..., hlm.121 
TAHKIM, Jurnal Peradaban dan Hukum Islam. Vol.4 No.l (Maret, 2021) | ISSN : 2597-7962

Apabila dalam sebuah kegiatan ekonomi mengandung kedzaliman terhadap salah satu pihak atau pihak manapun juga, maka niscaya haram hukumnya berdasarkan AlQur'an Surat An-Nisa' ayat 29. Seperti halnya transaksi atau kegiatan ekonomi yang dilakukan oleh satu pihak saja seperti yang terjadi dalam insider trading, transaksi antar sesama holding company, atau dalam bai' najasy.

Bai' najasy merupakan rekayasa pasar dalam permintaan (demand) yang terjadi jika produsen menciptakan permintaan palsu, sehingga kesannya ada banyak permintaan terhadap harga sebuah produk hingga menyebabkan harga jual produk tersebut naik. Praktik demikian dapat terbentuk misalnya dalam kasus bursa saham (menggoreng saham), bursa valas, dan lain sebagainya. Berbagai macam cara digunakan untuk menyebar isu, adanya order pembelian yang fiktif, hingga adanya pembelian pancingan untuk menaikkan sentimen pasar. Jika harga sudah naik sesuai yang diinginkan, maka penjual akan mengambil keuntungan dengan melepaskan kembali saham atau mata uang yang telah dibeli, sehingga dia akan memperoleh keuntungan dengan jumlah yang tinggi. ${ }^{29}$ Berdasarkan apa yang diatur dalam syarat sah yang menyatakan bahwa akad harus dilaksanakan oleh dua pihak secara berbilang, arti kata tidak boleh dilakukan dengan seorang diri dengan tujuan mengelabuhi atau mendzalimi pihak lain. Transaksi yang demikian seperti bai' najasy sangat dilarang dan tidak memenuhi syarat dari 'aqidain yang mengharuskan berbilang.

\section{Syarat In'iqad Pernyataan Kehendak (Shighat) dalam Akad}

Sighat akad atau disebut pernyataan kehendak diartikan sebagai suatu ungkapan para pihak yang melakukan akad yang berupa ijab dan qabul. Sebagaimana ijab merupakan sebuah pernyataan janji atau penawaran dari pihak pertama untuk melakukan atau tidak melakukan sesuatu. Sedangkan qabul merupakan sebuah bentuk pernyataan penerimaan atas penawaran yang dilakukan oleh pihak pertama dari pihak kedua. Dari berlangsungnya ijab dan qabul tersebut harus dapat menjelaskan maksud adanya

\footnotetext{
${ }^{29}$ Adiwarman Karim, Bank Islam..., hlm.78.
} 
TAHKIM, Jurnal Peradaban dan Hukum Islam. Vol.4 No.l (Maret, 2021) | ISSN : 2597-7962

perizinan, ridha, persetujuan yang menggambarkan kesepakatan antara kedua belah pihak yang berakad atas adanya konsekuensi hak dan kewajiban. ${ }^{30}$

Sighat dalam sebuah akad merupakan salah satu rukun yang memiliki peran sebagai pengikat dalam menjalankan esensi akad yakni lewat adanya ijab-qabul. Adapun syarat yang melekat dan harus dipenuhi oleh para pihak dalam mengadakan ijab dan qabul adalah sebagai berikut:

a. Persesuaian antara ijab dan qabul

Pernyataan qabul disyaratkan adanya keselarasan atau persesuaian terhadap ijab dalam banyak hal. Pernyataan jawaban yang tidak sesuai dengan ijab tidak dinamakan sebagai qabul. ${ }^{31}$ Perkataan atau hal lain yang digunakan untuk menyatakan kehendak batin inilah yang disebut sebagai shighat akad. ${ }^{32}$ Pernyataan kehendak dalam hukum perjanjian syariah dapat dinyatakan melalui beberapa cara yakni secara lisan, melalui tulisan, dengan isyarat, dan secara diam-diam (at-ta'ati). ${ }^{33}$

Sangat mudah ditemukan permasalahan di kalangan masyarakat terkait dengan bentuk pernyataan kehendak ini, misalnya dalam jual beli mu'athah yang hanya mendasarkan kehendaknya pada perbuatan. Bentuknya seperti pembeli yang cukup meletakkan uang dan penjual menyerahkan barangnya. Transaksi mu'athah ini biasa kita temukan dalam transaksi di supermarket, pasar, dan mall. Terdapat ikhtilaf di kalangan ulama terkait dengan bentuk yang digunakan dalam ijab-qabul, sebagaian ada yang tidak membolehkan menggunakan perbuatan dan sebagian lagi menyatakan boleh mengunakan sebuah perbuatan untuk menyatakan kehendak (ijab dan qabul).

Ulama di kalangan Syafi'iyah melarang bentuk perbuatan dalam ijab qabul karena perbuatan tidak menunjukkan adanya 'iwadh atau timbal balik. Sehingga jual beli mu'athah semacam ini menurut ulama Syafi'i tidaklah sah. Asy Syairozi mengatakan bahwa tidaklah sah akad jual beli kecuali adanya ijab-qabul dan jual beli mu'athah tidak sah dan tidak disebut sebagai jual beli. Imam Nawawi juga menegaskan

\footnotetext{
${ }^{30}$ Mustafa Ahmad az-Zarqa, Al-Madkhal..., I: 292

${ }^{31}$ Ghufron A. Mas'adi, Fiqh Mua'malah Kontemporer, (Jakarta: Rajawali Pers, 2002) hlm. 95.

${ }^{32}$ Ali al-Khafif, Mukhtasar Ahkam al-Mu'amalat asy-Syar'iyyah, (Kairo: tapi, 1957) hlm. 75.

${ }^{33}$ Ahmad Azhar Basyir, Asas-asas Hukum.., hlm. 69.
} 
TAHKIM, Jurnal Peradaban dan Hukum Islam. Vol.4 No.l (Maret, 2021) | ISSN : 2597-7962

tentang perkara ini dengan menyebutkan bahwa pendapat yang masyhur dalam madzhab Syafi'i yaitu jual beli tidaklah sah kecuali dengan adanya ijab dan qabul, sedangkan jual beli mu'athah tidaklah sah baik bentuknya sedikit maupun banyak. ${ }^{34}$

Dapat dipahami bahwa jual beli atau akad lain yang dilakukan dengan perbuatan atau dikategorikan sebagai at-ta'ati dalam menjawab perkembangan perekomonian adalah sebuah realitas yang harus diperbolehkan atas dasar keridhaan antara kedua belah pihak. Pertimbangan yang dapat digunakaan untuk membolehkan hal demikian adalah misalnya terdapat dua kaidah yang menyatakan bahwa kebiasaan merupakan sebuah hukum dan dasar dari setiap suatu perbuatan adalah boleh hingga ada perintah yang mengharamkannya.

b. Adanya kesatuan Majelis Akad

Kesatuan majelis dalam sebuah akad menjadi salah satu syarat yang harus dipenuhi dari sighat akad, yakni harus bersatu majelis antara para pihak yang melangsungkan ijab dan qabul. Para ulama menyatakan bahwa salah satu syarat akad adalah harus dilaksanakan dalam satu majelis akad. Majelis akad adalah suatu tempat dan waktu dimana kedua belah pihak berada pada saat negosiasi yang dimulai dari saat diajukannya ijab dan berlangsung selama mereka tetap fokus pada masalah perundingan perjanjian serta berakhir dengan berpalingnya mereka dari negosiasi tersebut. Teori mengenai majelis akad pada umumnya digunakan untuk menentukan kapan dan dimana akad tersebut dilakukan, dan secara khusus untuk menentukan kapan qabul dapat diberikan serta ditujukan untuk memberikan kesempatan kepada kedua belah pihak guna mempertimbangkan akad tersebut. ${ }^{35}$

Majelis akad adalah keadaan di mana kedua pengakad sedang pelaksanakan proses akad. Atau dengan kata lain samanya ucapan tentang objek akad. Ada tiga syarat untuk mewujudkan substansi bersambungnya qabul dengan ijab yaitu Pertama, keduanya berada dalam majelis yang sama. Kedua, tidak muncul dari salah seorang pengakad sesuatu yang mengindikasikan ia berpaling dari akad. Ketiga, mujib tidak

${ }^{34}$ Imam Abi Zakariya An-Nawawi, Al-Majmu’ Syarah Al Muhadzab Jilid 9, (Beirut: Darul Fikr, tt) hlm, 115.

${ }^{35}$ Syamsul Anwar, Hukum Perjanjian Syariah..., hlm. 147-151 
TAHKIM, Jurnal Peradaban dan Hukum Islam. Vol.4 No.l (Maret, 2021) | ISSN : 2597-7962

menarik kembali ijabnya sebelum adanya qabul dari qabil. Syarat pertama, satu majelis ijab dan qabul. Maka tidak boleh jika ijab dalam satu majelis, sementara qabul dalam majelis yang lain, karena ijab tidak dianggap sebagai bagian dari akad kecuali apabila diikuti oleh qabul. ${ }^{36}$

Mengenai perpindahan saat melakukan akad (ijab-qabul), apabila seorang penjual berpindah ke tempat yang lain jauh dari majelisnya yang pertama sejauh dua atau tiga meter atau ia berpindah ke kamar yang lain maka berakhirlah majelis pertama. Apabila qabil mengucapkan qabulnya setelah berpindahnya mujib akad dianggap tidak sah dan butuh kepada ijab yang baru lagi, karena ijab merupakan ungkapan maknawi yang tidak bisa tetap kalau tidak digandengkan dengan qabul dalam satu majelis.

Jumhur fuqaha (Hanafiyyah, Malikiyyah dan Hanabilah) menetapkan, tidak disyarat- kan segera dalam mengucapkan qabul, karena qabil butuh waktu untuk berpikir, maka kalau disyaratkan mesti langsung tentu ia tidak bisa untuk berpikir. Yang penting, qabul itu muncul dalam majelis yang sama meskipun waktunya cukup panjang sampai akhir majelis, karena majelis yang masih satu dapat menghimpun halhal yang terpisah dalam kondisi terpaksa.

Pensyaratan mesti langsung akan menyulitkan bagi si qabil atau menghilangkan kesempatan untuk jual beli baginya tanpa kemaslahatan yang jelas. Jika ia langsung menolak maka ia akan kehilangan peluang berjual beli dan jika ia langsung menerima, boleh jadi ia akan melakukan akad yang mengandung kemudharatan. Maka, dibutuhkan waktu untuk berpikir guna mempertimbangkan antara mengambil atau beruntung dan antara memberi atau merugi dalam melakukan akad. Waktu untuk berpikir itu dihitung sesuai dengan lamanya majelis akad, karena sebuah majelis dapat menghimpun hal-hal yang terpisah. Beberapa jenak atau satu jam (tergantung pada bentuk akad) bisa dijadikan ukuran untuk memudahkan manusia dan mencegah timbulnya rasa terpaksa, tidak ridha dan untuk menghindari adanya kemudharatan yang akan menimpa pengakad sedapat mungkin.

\footnotetext{
${ }^{36}$ Wahbah Az-Zuhaily. Al-Fiqh Al-Islami..., IV: 101
} 
TAHKIM, Jurnal Peradaban dan Hukum Islam. Vol.4 No.l (Maret, 2021) | ISSN : 2597-7962

Pemahaman tentang kesatuan dalam majelis akad seharusnya tidak dimaknai dengan kaku sebatas ukuran kesamaan ruang dan waktu. Konsep kesatuan majelis akad seyogyanya diperluas seiring perkembangan teknologi. Kesatuan majelis dalam hal ini akan terasa tidak memiliki arti jika para pelaku yang mengadakan akad meskipun secara fisik bertemu akan tetapi tidak terjadi kesesuaian kehendak dari pihak yang lain saat melakukan transaksi. Sebaliknya mungkin akan lebih terasa kesesuaian secara subtantif apabila sebuah transaksi dilakukan secara berjauhan akan tetapi terjadi kesepakatan antara kedua belah pihak.

Pemaknaan terhadap kesatuan majelis akad tidak hanya sebatas kesatuan dalam tempat dan waktu, karena akan sulit untuk diterapkan di tengah kemajuan peradaban kontemporer yang tidak menutup kemungkinan untuk terciptanya kesepakatankesepakatan melalui alat komunikasi yang bersifat virtual. Oleh karena itu, yang dimaksud dengan kesatuan majelis akad di sini yaitu kesatuan waktu pelaksanaannya. Bukan terletak pada kesatuan tempat secara fisik. Sebagai ketentuan dalam kesatuan majelis dalam hal ini masih berada pada perhatian untuk menyelesaikan perjanjian atau transaksi yang dibuat. Apabila telah berpindah fokus, maka majelis akad tersebut sudah dianggap berakhir. Dengan demikian, akad dengan ijab melalui telepon atau alat komunikasi lain adalah majelis sejak dibuatnya ijab melalui telepon atau dikirimkannya surat sampai ada jawaban dari pihak lawan. Ijab dianggap berakhir ketika pembicaraan dialihkan kepada soal lain sebelum qabul dinyatakan. Sama halnya dalam dunia bisnis e-commers, ketentuan yang telah tertera dalam spesifikasi produk merupakan penyesuaian dalam ijab qabul dan apabila pembeli menyatakan kesediaannya untuk melakukan transaksi, maka hal itu dianggap sebagai sebuah kesepakatan dalam akad. ${ }^{37}$

\section{SIMPULAN}

Berdasarkan pemaparan dan analisis terhadap syarat in'iqad dari 'aqidain (para pihak) dan shighat (ijab qabul) dalam pembentukan akad syariah serta aplikasinya pada

${ }^{37}$ Ibid.., hlm. 445 
TAHKIII, Jurnal Peradaban dan Hukum Islam. Vol.4 No.l (Maret, 202I) | ISSN : 2597-7962

kegiatan ekonomi di atas, maka dapat disimpulkan bahwa takwin al-Aqd atau pembentukan sebuah akad akan dapat terwujud apabila telah terpenuhi segala unsur-unsurnya. Rukun akad yang masyhur meliputi para pihak yang berakad ('aqidain), objek yang diakadkan (ma'qud 'alaih), tujuan atau maksud mengadakan akad (maudhu' al- 'aqad), dan sighat al-'aqad (ijab dan qabul). Seorang manusia sejak awal kehidupannya di dalam perut ibunya sampai menjadi seorang yang dewasa akan melalui lima fase yaitu fase janin, fase anak-anak (belum mumayyiz), fase mumayyiz, fase baligh, dan fase ar-rusyd (berakal sempurna atau dewasa).

Syarat In 'iqad pada para pihak yang mengadakan akad meliputi tamyiz dan berbilang. Sedangkan syarat In'iqad pada pernyataan kehendak (shighat) harus terjadi persesuaian antara ijab dan qabul serta harus dalam kesatuan majlis. Syarat-syarat tersebut harus dipenuhi agar akad yang dilaksanakan dapat sah dan berlaku kepada kedua belah pihak. Apabila syarat tersebut tidak terpenuhi, maka transaksi ekonomi yang dilakukan akan bernilai tidak sah. 
TAHKIM, Jurnal Peradaban dan Hukum Islam. Vol.4 No.l (Maret, 2021) | ISSN : 2597-7962

\section{DAFTAR PUSTAKA}

\section{Buku}

A Karim, Adiwarman. (2007). Bank Islam, Cet. III. Jakarta: Raja Grafindo.

Al-Ba'alawy, Sayyid Abdurrahman bin Muhammad. (1994). Bughyatul Mustarsyidin. Beirut: Darul Kutub Ilmiyah.

Al-Hushny, Taqiyuddin Abu Bakar. (1993). Kifayatul Akhyar fi Hilli Ghayatil Ikhtishar. Surabaya: Al-Hidayah.

Al-Khafif, Ali. (1952). Mukhtasar Ahkam al-Mu'amalat asy-Syar'iyyah. Kairo: tp.

An-Nawawi, Imam Abi Zakariya. (1996). Al-Majmu’ Syarah Al Muhadzab Jilid 9. Beirut: Darul Fikr.

. (2007). Hukum Perjanjian Syariah, Studi tentang Teori Akad dalam Fikih Muamalat. Jakarta: Rajawali Pers.

Ascara. (2007). Akad Dan Produk Bank Syariah. Jakarta: Rajawali Pers.

Ash-Shiddieqy, Hasbi. (1999). Pengantar Fiqih Mu'amalah. Jakarta: Bulan Bintang. . (2007). Pengantar Fiqh Mu'amalah, ed. 2. Semarang: Pustaka Rizki

Putra.

Az-Zarqa, Mustafa Ahmad. (1968). al-Madkhal al-Fiqh al'Am. Beirut: Darul Fikr.

Az-Zuhaili, Wahbah. (1989). al-Fiqh al-Islami wa Adillatuhu. Damaskus: Darul Fikr.

Azzam, Abdul Aziz Muhammad. (2013). Fiqih Muamalat. Jakarta: Amzah.

Basyir, Ahmad Azhar. (2000). Asas-asas Hukum Muamalat. Yogyakarta: UII Press.

Dahlan, Abdul Azis. (1996). Ensiklopedi Hukum Islam, Jilid I Cet. I . Jakarta: Ichtiar Baru Van Hoeve.

Dewi, Wirdyaningsih Gemala dan Yeni Salma Barlint. (2006). Hukum Perikatan Islam di Indonesia. Jakarta: Kencana.

Hadi, Sutrisno. Metodologi Riset. Yogyakarta: Pustaka Belajar, 2019.

Nadzir, Muh. Metode Penelitian. Jakarta: Ghalia Indonesia, 1998.

Hasan, Nurul Ichsan. (2014). Perbankan Syariah: Sebuah Pengantar. Jakarta: Referensi GP Press Group. 
TAHKIM, Jurnal Peradaban dan Hukum Islam. Vol.4 No.l (Maret, 2021) | ISSN : 2597-7962

Kamali, Muhammad Hashim. (1996). Prinsip dan Teori-teori Hukum Islam. Yogyakarta: Pustaka Pelajar.

Mardani. (2012). Fiqih Ekonomi Syariah. Jakarta: Kencana.

Mas'adi, Ghufron A. (2002). Fiqh Mu'amalah Kontemporer.Jakarta: Rajawali Pers.

Nadzir, Muh. (1998). Metode Penelitian. Jakarta: Ghalia Indonesia.

\section{Jurnal}

Afdawaiza. (2008). Terbentuknya Akad, Jurnal Al-Mawarid Edisi XVIII.

Anwar, Syamsul. (1996). Hukum Perjanjian dalam Islam; Kajian Terhadap Masalah Perizinan (Toestemming) dan Cacat Kehendak (Wilsgerbrek). Laporan Penelitian Pada Balai Penelitian P3M Institut Agama Islam Negeri Sunan Kalijaga Yogyakarta.

Darmawati. (2018). Akad Dalam Transaksi Ekonomi Syari'ah. Sulesana: Jurnal Wawasan Keislaman, Volume 12 Nomor 2.

Leu, Urbanus Uma. (2014). Akad dalam Transaksi Ekonomi Syariah. Jurnal Tahkim IAIN Ambon Vol. 10 No. 1. 